\author{
Izabela KONKOL $^{1 *}$, Jan CEBULA ${ }^{1}$, Jolanta BOHDZIEWICZ ${ }^{2}$, Krzysztof PIOTROWSKI $^{3}$ \\ Piotr SAKIEWICZ ${ }^{4}$, Magdalena PIECHACZEK-WERESZCZYŃSKA ${ }^{5}$ \\ and Adam CENIAN ${ }^{1}$
}

\title{
MINERAL DEPOSIT FORMATION IN GAS ENGINES DURING COMBUSTION OF BIOGAS FROM LANDFILLS AND MUNICIPAL WWTP
}

\begin{abstract}
The biogas produced in municipal wastewater-treatment plants (WWTP) should be cleaned before it can be used as a fuel in internal combustion engines. Efficient running of such engines is possible only subject to using high quality biogas and lubricating oil. Otherwise, biogas impurities in course of complex chemical reactions may form deposits on various engine parts as well as seriously contaminate the lubricating oil. In this paper, mineral deposits containing high concentration of bismuth, silicon, sulphur, calcium and zinc are studied. Silicon deposits demonstrating strong friction properties are formed during combustion of volatile silica compounds. As these deposits build up, abrasion problems, ignition failure and even engine failure result. The bismuth containing deposits comes from bearings degradation, zinc and calcium were derived from the additives present in commercially available lubricating oil, while lead, aluminium, copper, nickel, iron and chromium were introduced by engine wear phenomena. The highest bismuth content was located at the engine cylinder heads and the lowest at the exhaust elements, whereas highest calcium content was registered on the pistons. Silicon containing deposits are highest in the exhaust and lowest at the engine head. Zinc deposits are highest at the piston.
\end{abstract}

Keywords: biogas, carbonyls, deposits, gas engine, siloxanes

\section{Introduction}

Biogas is produced during anaerobic digestion of organic matter. From the point of view of renewable energy production, to be a viable fuel should contain at least $60 \%$ of methane and low amounts of impurities. In addition to methane and carbon dioxide, biogas contains other compounds that inhibit or preclude its use. The compounds that cause difficulties in its use include volatile compounds of sulphur (mainly hydrogen sulphide and

\footnotetext{
${ }^{1}$ Physical Aspects of Ecoenergy Department, Institute of Fluid-Flow Machinery, Polish Academy of Sciences, ul. S. Fiszera 14, 80-231 Gdańsk, Poland, phone +48 5852251 88, email: izabela.konkol@imp.gda.pl, jcebula@imp.gda.pl, cenian@imp.gda.pl

${ }^{2}$ Faculty of Energy and Environmental Engineering, Silesian University of Technology, ul. S. Konarskiego 18, 44-100, Gliwice, Poland, phone + 483223727 77, email: jolanta.bohdziewicz@ polsl.pl

${ }^{3}$ Faculty of Chemistry, Silesian University of Technology, Gliwice, ul. M. Strzody 7, 44-100, Gliwice, Poland, phone + 483223719 00, email: krzysztof.piotrowski@polsl.pl

${ }^{4}$ Faculty of Mechanical Engineering, Silesian University of Technology, Gliwice, ul. S. Konarskiego 18A, 44-100, Gliwice, Poland, phone +48 3223720 47, email: piotr.sakiewicz@polsl.pl

${ }^{5}$ Faculty of Natural and Technical Sciences, University of Opole, Opole, ul. kard. B. Kominka 6, 45-032 Opole, Poland, phone +48 7740160 50, email: biotechnologia@uni.opole.pl

*Corresponding author: izabela.konkol@imp.gda.pl
} 
mercaptans), silicon (silanes and siloxanes), hydrogen phosphide and nitrogen compounds (ammonia and amines). Organosilicon compounds are widely used in many applications such as antifoaming agents, coatings, shampoos and cosmetics. Particles of organosilicon compounds present in the aqueous phase are especially concentrated on the surface of sewage sludge and then released during the methane fermentation process [1-3]. Despite the frequent detection of siloxanes in the sludge and produced biogas, so far, their fate during anaerobic digestion of the sludge has not been investigated [1].

Decades after identifying silicon dioxide in exhaust gas from engines powered by biogas from municipal wastewater treatment plants and landfill biogas, a wide range of research was carried out on various stages of the life cycle of siloxanes. The cycle begins with the production and use of polydimethylsiloxane polymers in a wide range of industrial and domestic applications and their further dispersion in various environmental facilities.

It is now known that siloxanes after partial depolymerisation are introduced into wastewater treatment plants, where due to their low biodegradability and high affinity for settling on the surface of solid particles, they are first transferred from wastewater into sludge and then volatilized into the gas phase - biogas. If the organic silicon components reach the combustion chamber, they burn, producing the typical components of combustion (carbon dioxide and water). The silicon also forms silica $\left(\mathrm{SiO}_{2}\right)$ or silicates, which are partly removed with exhaust gases, but which are also deposited on all components of the engine [4-6]. Deposits are visible in the form of sediment with smooth or rough structure in various shades of grey, they also can create layers a few millimetres thick which are difficult to remove. These mineral structures, which have abrasive properties, also include chemical compounds formed due to the presence of refining additives contained in engine oils $[7,8]$.

During combustion, the main siloxanes (e.g. D4, D5 and D6 from Table 1) are oxidized to silicon dioxide $\left(\mathrm{SiO}_{2(\mathrm{~s})}\right)[3,9]$ :

$$
\begin{aligned}
& \left(\left(\mathrm{CH}_{3}\right)_{2} \mathrm{SiO}\right)_{4}+16 \mathrm{O}_{2} \rightarrow 4 \mathrm{SiO}_{2}+8 \mathrm{CO}_{2}+12 \mathrm{H}_{2} \mathrm{O} \\
& \left(\left(\mathrm{CH}_{3}\right)_{2} \mathrm{SiO}\right)_{5}+20 \mathrm{O}_{2} \rightarrow 5 \mathrm{SiO}_{2}+10 \mathrm{CO}_{2}+15 \mathrm{H}_{2} \mathrm{O} \\
& \left(\left(\mathrm{CH}_{3}\right)_{2} \mathrm{SiO}\right)_{6}+24 \mathrm{O}_{2} \rightarrow 6 \mathrm{SiO}_{2}+12 \mathrm{CO}_{2}+18 \mathrm{H}_{2} \mathrm{O}
\end{aligned}
$$

During the silica condensation, nanoparticles and nanoclusters are progressively formed and continue to grow establishing larger aggregates. When the deposit is considerable in size, abrasion problems, ignition failure and even engine failure result $[4,5]$.

Table 1 presents selected properties of commonly occurring organosilicon compounds in biogas. Most siloxanes found in wastewater treatment plants are in the form of $\mathrm{D}_{4}, \mathrm{D}_{5}$ and $\mathrm{D}_{6}$ [10]. Similarly, most of these compounds are found in biogas [11, 12]. Siloxanes are relatively long life in water, because they are not biodegradable [3], however they can undergo hydrolysis (using acid and base-catalysed process) with estimated half-lives ranging from a few hours even up to 100 days, depending on the compound type, temperature and $\mathrm{pH}[13,14]$. The presence of surfactants in the fermentation chamber promotes the volatility of siloxanes $[1,15]$.

The technologies to remove siloxanes from biogas can be divided into pretreatment and post-purification methods. These differ in respect to mechanisms and efficiencies. The pretreatment methods focus on removal of siloxanes when they are in wastewater and before the final anaerobic digestion, while post-purification methods focus on add-on technologies to remove them from the generated biogas [17]. 
Physical properties of selected organosilicon compounds in biogas $[3,6,16]$

\begin{tabular}{|c|c|c|c|c|c|}
\hline \multirow{2}{*}{ Name } & \multirow{2}{*}{ Abbr. } & \multirow{2}{*}{$\begin{array}{l}\text { Chemical } \\
\text { formula }\end{array}$} & $\begin{array}{c}\text { Boiling } \\
\text { point }\end{array}$ & $\begin{array}{c}\text { Vapour } \\
\text { pressure }\end{array}$ & Water solubility \\
\hline & & & {$\left[{ }^{\circ} \mathbf{C}\right]$} & $\begin{array}{c}{[\mathrm{Pa}]} \\
\text { at } 25^{\circ} \mathrm{C}\end{array}$ & $\begin{array}{c}{\left[\mathrm{mg} \cdot \mathrm{dm}^{-3}\right]} \\
\text { at } 25^{\circ} \mathrm{C}\end{array}$ \\
\hline Hexamethyldisiloxane & $\mathrm{L}_{2}$ & $\mathrm{C}_{6} \mathrm{H}_{18} \mathrm{OSi}_{2}$ & 106.9 & 5626.2 & 0.93 \\
\hline Octamethyltrisiloxane & $\mathrm{L}_{3}$ & $\mathrm{C}_{8} \mathrm{H}_{24} \mathrm{O}_{2} \mathrm{Si}_{3}$ & 153.0 & 445.0 & 0.034 \\
\hline Decamethyltetrasiloxane & $\mathrm{L}_{4}$ & $\mathrm{C}_{10} \mathrm{H}_{30} \mathrm{O}_{3} \mathrm{Si}_{4}$ & 194.0 & 50.0 & 0.00674 \\
\hline Dodecamethylpentasiloxane & $\mathrm{L}_{5}$ & $\mathrm{C}_{12} \mathrm{H}_{36} \mathrm{O}_{4} \mathrm{Si}_{5}$ & 232.0 & 9.0 & 0.000309 \\
\hline Hexamethylcyclopentasiloxane & $\mathrm{D}_{3}$ & $\mathrm{C}_{6} \mathrm{H}_{18} \mathrm{O}_{3} \mathrm{Si}_{3}$ & 135.2 & 471.0 & 1.56 \\
\hline Octamethylcyclotetrasiloxane & $\mathrm{D}_{4}$ & $\mathrm{C}_{8} \mathrm{H}_{24} \mathrm{O}_{4} \mathrm{Si}_{4}$ & 175.7 & 132.0 & 0.056 \\
\hline Decamethylcyclopentasiloxane & $\mathrm{D}_{5}$ & $\mathrm{C}_{10} \mathrm{H}_{30} \mathrm{O}_{5} \mathrm{Si}_{5}$ & 211.2 & 23.2 & 0.017 \\
\hline Dodecamethylcyclohexasiloxane & $\mathrm{D}_{6}$ & $\mathrm{C}_{12} \mathrm{H}_{36} \mathrm{O}_{6} \mathrm{Si}_{6}$ & 245.1 & 4.0 & 0.005 \\
\hline
\end{tabular}

Generally the biodegradation, gas stripping and peroxidization are the three typical pretreatment methods (biological, physical and chemical ones), whereas their chemical decomposition and recovery constitute the post-purification technologies. Post-purification technologies can be divided into recovery and decomposition methods (adsorption, absorption, membrane separation, catalytic oxidation, biological degradation and photocatalysis) $[3,17,18]$.

Modern technologies for siloxane removal from biogas are mainly based on physical adsorption using such sorbents as activated carbon, silica gels, zeolites and molecular sieves $[19,20]$. Above $99 \%$ of siloxane removal efficiency in accessible technologies can be achieved, reducing their concentrations to below $0.1 \mathrm{mg} \cdot \mathrm{m}^{-3}[3,17,18]$. Adsorbing materials (carbon-based materials) with a meso- and microporous structure seem to be the most technologically, technically and economically suitable [3].

Reduction of siloxanes in biogas can be achieved by thermal treatment of sewage sludge before the anaerobic fermentation process. For example, removal efficiency of $90 \%$ was achieved by purging sewage sludge with air at $80{ }^{\circ} \mathrm{C}$ for 48 hours (flow rate of $0.5 \mathrm{dm}^{3} \cdot \mathrm{min}^{-1}$ ) [21]. Siloxanes dissolve in organic solvents such as toluene, acetone, xylem, suggesting the possibility of their removal from biogas by absorption methods [22]. At temperatures below freezing and under reduced pressure, some of the compounds present in biogas condense and can be separated. Cooling biogas with water condensation promotes siloxanes removal, further removal occurs on the appropriate sorbents - this method allows $90 \%$ of organosilicon compounds to be removed from the biogas.

Gas chromatography coupled with mass spectrometry (GC-MS) is the most common technique for siloxanes quantification. Different sampling techniques have been assessed such as Tedlar bags and adsorbent tubes [23, 24]. Landfill gas or biogas may contain siloxanes usually in the concentration range of several milligrams in a cubic meter. It was found, that the siloxane content depends on the fermentation temperature and the composition of treated wastewater. The maximal content of siloxanes $D_{4}$ in biogas determined analytically was $1.5-10.1 \mathrm{mg} \cdot \mathrm{m}^{-3}$ whereas of $\mathrm{D}_{5}$ varied from 10.8-124.0 $\mathrm{mg} \cdot \mathrm{m}^{-3}$ [25].

The appearance of deposits, especially carbon deposits in engines is significantly influenced by the quality of spray process, engine power, fuel consumption, etc. There is no information about carbon deposit composition available in the literature. Attention was paid 
mainly to the possibility of production of metal carbonyls, which can be the source of some deposit fractions. Volatile metal compounds are present e.g. in gases emitted during the combustion of hard coal, lignite, wood, sewage sludge, gasification of biomass, landfill biogas, biogas from municipal sewage-sludge treatment-plant or combustion of fuel in gas engines.

The collected information from the literature on carbonyls indicates their occurrence in the form of single-core $\mathrm{M}(\mathrm{CO})_{\mathrm{x}}$ and multi-core $\mathrm{M}_{\mathrm{n}}(\mathrm{CO})_{\mathrm{x}}$ species. Some examples of carbonyls are summarized in Table 2 .

Table 2

Boiling and melting points of selected carbonyls

\begin{tabular}{|c|c|c|c|c|}
\hline \multirow{2}{*}{ Chemical formula } & Melting point & Boiling point & \multirow{2}{*}{ Chemical formula } & \multirow{2}{*}{$\begin{array}{c}\text { Melting point } \\
{\left[{ }^{\circ} \mathrm{C}\right]}\end{array}$} \\
\hline & \multicolumn{2}{|c|}{$\left[{ }^{\circ} \mathbf{C}\right]$} & & \\
\hline $\mathrm{Fe}(\mathrm{CO})_{5}$ & -20 & 103 & $\mathrm{Fe}_{2}(\mathrm{CO})_{9}$ & 100 \\
\hline $\mathrm{Ni}(\mathrm{CO})_{4}$ & -19 & 42.1 & $\mathrm{Fe}_{3}(\mathrm{CO})_{12}$ & 140 \\
\hline $\mathrm{Co}(\mathrm{CO})_{4}$ & 52 & - & $\mathrm{Co}_{2}(\mathrm{CO})_{8}$ & 51 \\
\hline $\mathrm{Cr}(\mathrm{CO})_{6}$ & 150 & 220 & $\mathrm{Co}_{4}(\mathrm{CO})_{12}$ & - \\
\hline $\mathrm{Mo}(\mathrm{CO})_{6}$ & 150 & 156 & $\mathrm{Co}_{6}(\mathrm{CO})_{16}$ & - \\
\hline $\mathrm{Mn}(\mathrm{CO})_{5}$ & 154 & - & $\mathrm{Mn}_{2}(\mathrm{CO})_{10}$ & 155 \\
\hline $\mathrm{W}(\mathrm{CO})_{6}$ & 150 & 175 & $\mathrm{Os}_{3}(\mathrm{CO})_{12}$ & - \\
\hline $\mathrm{Ru}(\mathrm{CO})_{5}$ & -22 & - & $\mathrm{Ir}_{2}(\mathrm{CO})_{8}$ & - \\
\hline $\mathrm{Os}(\mathrm{CO})_{4}$ & 224 & - & $\mathrm{Rh}_{4}(\mathrm{CO})_{12}$ & - \\
\hline
\end{tabular}

Carbonyls occur at room temperature in gaseous, liquid or solid forms. These are toxic, easily reactive with water, halides, etc. Carbonyls are formed by synthesis of metal with carbon monoxide:

$$
\mathrm{Ni}+4 \mathrm{CO} \rightarrow \mathrm{Ni}(\mathrm{CO})_{4}
$$

Reactions can occur at room temperature, under low or elevated $\mathrm{CO}$ partial pressure.

\section{Materials and methods}

The aim of the study was to determine elemental composition of deposit layers created during combustion. Deposits were collected from a gas engine powered by biogas manufactured in a municipal sewage treatment plant. The deposit samples analysed here were taken from various elements (e.g. piston, head and exhaust manifold) of one engine during its technical service (Fig. 1). Deposit samples were taken by scraping them from the parts on which they were deposited. Some of the deposits were loosely connected to the surface and could be easily removed from the metal surface. Rough, crystalline, opaque, grey coloured deposits were scraped off with a sharp knife, which was made of chrome-nickel steel. Deposit samples were ground in an agate mortar.

Phase composition of deposits was analysed by X-ray diffraction (XRD) and X-ray fluorescence (XRF). 
a)

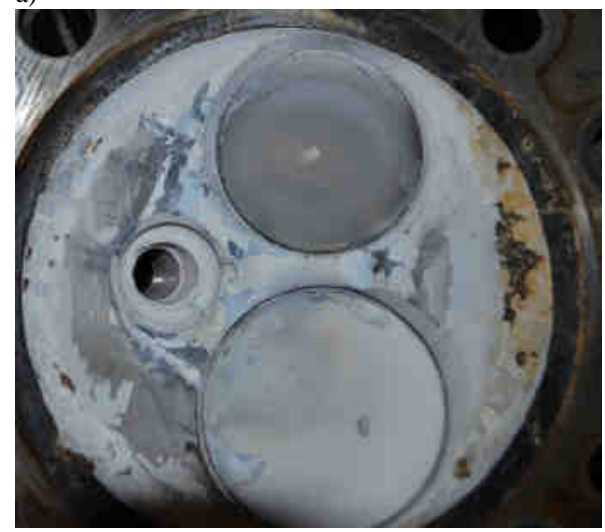

b)

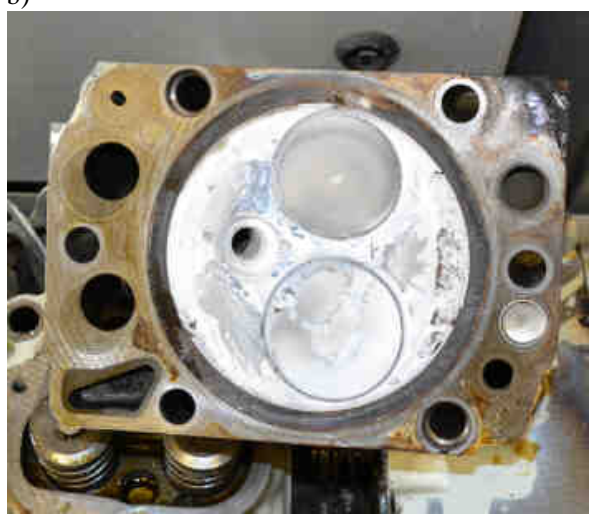

d)

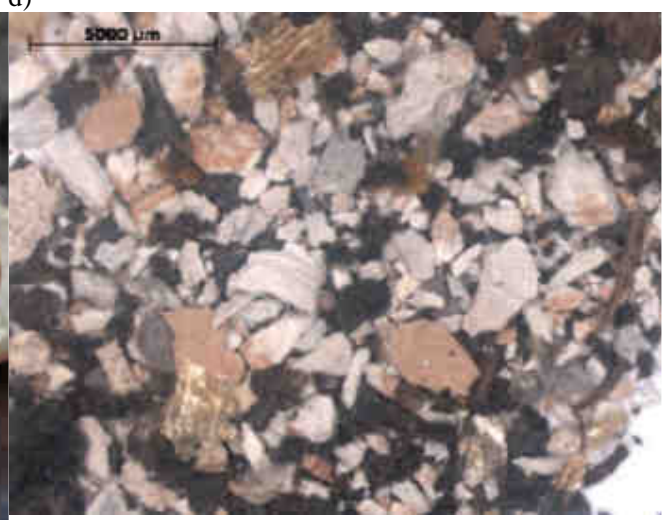

Fig. 1. The deposits formed resulting from thermochemical transformations of siloxanes: a), b) on engine parts, c) exhaust and d) deposits from head

\section{Results and discussion}

The composition of carbon deposits formed in the gas engines and its parts is correlated with biogas polluting compounds; this depends on the biogas source. Here we discuss the biogas produced in municipal waste-water plants and so-called landfill biogas.

\section{Deposits in engine powered by biogas from waste-water plant}

The deposits from the head (Table 3) showed significantly higher concentration levels of bismuth, silicon, calcium and sulphur.

The deposit separated from the piston demonstrates characteristic, very high content of bismuth, silicon, sulphur, calcium and zinc (Table 4). The content of bismuth (derived from bearings degradation) is lower than on engine head but calcium and silicon amount is higher. The presence of $\mathrm{Ca}$ and $\mathrm{S}$ in samples indicating the possibility of anhydrite or gypsum [7]. 
The XRF analysis results of carbon deposits from the gas engine head

\begin{tabular}{|c|c|c|c|c|c|}
\hline Element & Sample 1 & Sample 2 & Sample 3 & Sample 4 & Sample 5 \\
\hline [\%] & sample 1 & sample 2 & sample 3 & sample 4 & sample s \\
\hline $\mathrm{Bi}$ & 42.12 & 62.15 & 59.63 & 61.54 & 16.75 \\
\hline $\mathrm{O}$ & 31.06 & 16.91 & 19.82 & 24.26 & 40.78 \\
\hline $\mathrm{Ca}$ & 4.69 & 5.55 & 4.33 & 4.38 & 8.43 \\
\hline $\mathrm{Si}$ & - & 6.78 & 8.91 & 6.75 & 24.70 \\
\hline $\mathrm{S}$ & - & 5.83 & 2.61 & - & 4.53 \\
\hline $\mathrm{Na}$ & - & 0.04 & - & 0.21 & 0.26 \\
\hline $\mathrm{Zn}$ & 1.50 & 2.13 & 2.65 & 1.74 & 1.49 \\
\hline $\mathrm{C}$ & 1.08 & 0.50 & 2.04 & 1.12 & 3.06 \\
\hline
\end{tabular}

The XRF analysis results of carbon deposits from the gas engine piston

Table 4

\begin{tabular}{|c|c|c|c|c|c|}
\hline $\begin{array}{c}\text { Element } \\
{[\%]}\end{array}$ & Sample 1 & Sample 2 & Sample 3 & Sample 4 & Sample 5 \\
\hline $\mathrm{Bi}$ & 32.67 & 36.14 & 50.89 & 41.54 & 36.92 \\
\hline $\mathrm{O}$ & 32.24 & 25.04 & 18.71 & 28.75 & 26.64 \\
\hline $\mathrm{Ca}$ & 9.07 & 12.63 & 9.39 & 7.84 & 9.47 \\
\hline $\mathrm{Si}$ & 16.38 & 12.95 & 12.26 & 12.86 & 14.70 \\
\hline $\mathrm{S}$ & 5.30 & 6.13 & 4.07 & 4.55 & 5.09 \\
\hline $\mathrm{Na}$ & 0.22 & - & - & 0.24 & - \\
\hline $\mathrm{Zn}$ & 2.34 & 4.19 & 4.06 & 2.79 & 3.80 \\
\hline $\mathrm{C}$ & 1.45 & 1.64 & 0.23 & 1.43 & 3.38 \\
\hline $\mathrm{Fe}$ & 0.33 & - & 0.39 & - & - \\
\hline $\mathrm{P}$ & - & 1.04 & - & - & - \\
\hline $\mathrm{Al}$ & - & 0.25 & - & - & - \\
\hline
\end{tabular}

The deposits separated in the exhaust manifold of the gas engine represents a high content of silicon, bismuth, calcium, sulphur and zinc (Tables 5 and 6). It should be noted that the amount of silicon is up to 2 times higher than on the piston, but the amount of bismuth and calcium is much lower. The highest amount of zinc is located on the piston (almost 2 times higher than on the other investigated engine parts).

The XRF analysis results of carbon deposits from the gas engine exhaust collector

Table 5

\begin{tabular}{|c|c|c|c|c|c|}
\cline { 1 - 4 } Element & Sample 1 & Sample 2 & Sample 3 & Sample 4 & Sample 5 \\
\cline { 1 - 5 }$[\mathrm{Si}]$ & 33.29 & 32.51 & 32.73 & 31.36 & 32.90 \\
\hline $\mathrm{Al}$ & - & 0.30 & 0.52 & - & - \\
\hline $\mathrm{Bi}$ & 27.74 & 12.84 & 15.07 & 24.66 & 15.07 \\
\hline $\mathrm{C}$ & - & 2.05 & 1.98 & 1.94 & 3.21 \\
\hline $\mathrm{Ca}$ & 1.76 & 2.19 & 3.01 & 2.97 & - \\
\hline $\mathrm{Co}$ & 0.72 & 0.46 & 0.80 & 1.05 & 0.57 \\
\hline $\mathrm{Fe}$ & 0.26 & - & - & - & - \\
\hline $\mathrm{O}$ & 35.04 & 48.93 & 45.17 & 36.87 & 48.24 \\
\hline $\mathrm{Zn}$ & 1.20 & 0.71 & 0.71 & 1.15 & - \\
\hline
\end{tabular}

The changing colours of the deposit indicates its heterogeneity. Its chemical composition depends on the combustion conditions (changes at the considered parts) and the composition of biogas impurities. It was found e.g. that the highest bismuth content was 
located at the engine head and the lowest at the exhaust (lowest temperature), whereas highest calcium content was registered on the piston. Silicon containing deposits are highest in the exhaust and lowest at the engine head. Zinc deposits are highest at the piston. So, compounds with a compact crystalline structure are deposited on the head and piston. Compounds with a loose structure are blown into the exhaust.

Stanuch et al. [7] studied surface structure. They observed that the layer adhering directly to the surface of the piston was smooth but the layer lying on top of the deposit was much more rough.

Table 6

The XRD analysis results of the deposit presented in oxides forms

\begin{tabular}{|c|c|c|c|c|}
\hline No. & Compound & $\begin{array}{c}\text { Mass fraction } \\
{[\%] \mathbf{~ m} / \mathbf{m}}\end{array}$ & Element & $\begin{array}{c}\text { Elements fraction } \\
{[\mathbf{\%} \mathbf{~ m} / \mathbf{m}}\end{array}$ \\
\hline 1 & $\mathrm{SiO}_{2}$ & 57.13 & $\mathrm{Si}$ & 26.71 \\
\hline 2 & $\mathrm{Bi}_{2} \mathrm{O}_{3}$ & 18.59 & $\mathrm{Bi}$ & 16.67 \\
\hline 3 & $\mathrm{SO}_{3}$ & 10.65 & $\mathrm{~S}$ & 4.27 \\
\hline 4 & $\mathrm{CaO}$ & 7.46 & $\mathrm{Ca}$ & 5.33 \\
\hline 5 & $\mathrm{P}_{2} \mathrm{O}_{5}$ & 2.42 & $\mathrm{P}$ & 1.06 \\
\hline 6 & $\mathrm{ZnO}$ & 1.52 & $\mathrm{Zn}$ & 1.22 \\
\hline 7 & $\mathrm{Na}_{2} \mathrm{O}$ & 0.78 & $\mathrm{Na}$ & 0.58 \\
\hline 8 & $\mathrm{Fe}_{2} \mathrm{O}_{3}$ & 0.58 & $\mathrm{Fe}$ & 0.41 \\
\hline 9 & $\mathrm{PbO}$ & 0.52 & $\mathrm{~Pb}$ & 0.48 \\
\hline 10 & $\mathrm{Cr}_{2} \mathrm{O}_{3}$ & 0.16 & $\mathrm{Cr}$ & 0.11 \\
\hline 11 & $\mathrm{ZrO}_{2}$ & 0.14 & $\mathrm{Zr}$ & 0.10 \\
\hline 12 & $\mathrm{NiO}_{13}$ & 0.06 & $\mathrm{Ni}$ & 0.05 \\
\hline & & & $\mathrm{O}$ & 43.01 \\
\hline
\end{tabular}

\section{Deposits in engine powered by landfill biogas}

In the case of the gas engine powered by landfill biogas, its deposits are characterized by high contents of silicon, calcium, phosphorus, sulphur and zinc (Table 7). This points to the necessity of purifying this biogas before its application. Gersen et al. [26] stated that the fraction of silicon oxides in the gas phase depends strongly upon the temperature and concentration of silicon present in the combustion products.

Chemical analyses of the deposits from the spark plugs of gas engine powered with landfill biogas

\begin{tabular}{|c|c|c|c|c|c|}
\hline$\frac{\text { Element }}{[\%]}$ & Sample 1 & Sample 2 & Sample 3 & Sample 4 & Sample 5 \\
\hline $\mathrm{O}$ & 43.19 & 50.94 & 36.35 & 49.62 & 47.20 \\
\hline $\mathrm{Fe}$ & - & - & 0.63 & - & - \\
\hline $\mathrm{Ca}$ & 12.30 & - & 10.28 & - & 8.51 \\
\hline $\mathrm{Si}$ & 28.42 & 43.12 & 25.25 & 44.27 & 19.57 \\
\hline $\mathrm{P}$ & 4.16 & - & 2.61 & - & 2.68 \\
\hline $\mathrm{S}$ & 2.75 & - & 4.92 & - & 4.09 \\
\hline Sn & - & - & 0.63 & - & - \\
\hline $\mathrm{Cu}$ & - & - & - & - & 2.39 \\
\hline $\mathrm{Na}$ & 0.69 & - & 1.67 & - & 1.67 \\
\hline $\mathrm{Ni}$ & - & - & - & 1.21 & - \\
\hline $\mathrm{Zn}$ & 5.86 & 1.35 & 13.14 & 1.32 & 6.31 \\
\hline $\mathrm{C}$ & 2.63 & 4.59 & 4.59 & 3.58 & 7.60 \\
\hline
\end{tabular}


Table 7 presents the results of chemical analyses of the deposits collected from the spark plug engine using biogas manufactured from a regional landfill.

In the landfill gas tested approximately $9.5 \pm 0.4 \mathrm{mg} / \mathrm{m}^{3}$ of total siloxanes was determined analytically, with the highest concentrations represented by $D_{4}$ $\left(5.0 \pm 0.2 \mathrm{mg} / \mathrm{m}^{3}\right)$, and $\mathrm{D}_{5}\left(2.9 \pm 0.1 \mathrm{mg} / \mathrm{m}^{3}\right)$ and $\mathrm{L}_{2}\left(1.6 \pm 0.1 \mathrm{mg} / \mathrm{m}^{3}\right)$ species. Samples collected from the engine heads, prior to the treatment of landfill gas with activated carbon, demonstrated high levels of silicon $(149,400 \pm 8,900 \mathrm{mg} / \mathrm{kg})$, as well as calcium $(70.84 \pm 17.75 \mathrm{~g} / \mathrm{kg})$, sulphur $(42.5 \pm 11.5 \mathrm{~g} / \mathrm{kg})$ and zinc $(0.022 \pm 0.007 \mathrm{~g} / \mathrm{kg})$. After purification of biogas with the activated carbon bed, the volatile silicon levels decreased significantly. However, the deposit showed higher sulphur content (104.56 $\pm 68.1 \mathrm{~g} / \mathrm{kg})$, which indicates that the activated carbon released a certain amount of sulphur during the oxidation process. Analyses indicated, that zinc and calcium were derived from the additives present in the commercially available lubricating oil, while lead, aluminium, copper, nickel, iron and chromium were introduced by engine wear phenomena [27].

Comparative studies were carried out on the composition and morphological characteristics of deposits formed in biogas engines powered with gaseous fuels derived from agricultural anaerobic digesters and from digesters integrated technologically with landfills. These deposit samples collected from biogas engines used at a power plant in Florida, USA, were analysed by SEM and energy dispersion spectroscopy (EDS). Similarities and differences between deposit samples derived from biogas engines powered with gaseous fuel from anaerobic digesters and biogas from landfills were analysed in terms of chemical composition and morphology. The sample corresponding to anaerobic fermentation biogas did not contain potassium, while calcium and zinc predominated. Relatively high levels of carbon were observed in crystalline scaling deposits formed during biogas combustion. The $\mathrm{C}: \mathrm{O}: \mathrm{Si}$ approached the 5:7:1 ratio in deposits obtained from biogas engines powered with the fuel from agricultural anaerobic digesters and 2:3.5:1 ratio in the deposits from engine powered with landfill gas. In general, the silicon species content in biogas derived from biogas plant integrated with municipal wastewater treatment plant was lower compared to their content in a biogas from landfill wastes. A higher content of phosphorus, sulphur and calcium was additionally identified in the sludge from agricultural biogas-powered engines [28].

It is very important to remove sulphur compounds from biogas before its use. Hydrogen sulphide is burned in a gas engine according to the reaction (Eq. (5) and (6)):

$$
\begin{gathered}
\mathrm{H}_{2} \mathrm{~S}+2 \mathrm{O}_{2} \rightarrow \mathrm{H}_{2} \mathrm{O}+\mathrm{SO}_{3} \\
\mathrm{SO}_{3}+\mathrm{H}_{2} \mathrm{O} \rightarrow \mathrm{H}_{2} \mathrm{SO}_{4}
\end{gathered}
$$

The sulphuric acid produced is responsible for the acidification of the oil, but in reaction with lubricating oil additives containing calcium ions it also forms calcium sulphate. This compound is also deposited on the gas engine elements.

\section{Conclusion}

Improperly purified biogas or improper combustion in engines can lead to the formation of large amounts of deposits. Metals present in reaction environment can react with carbon monoxide, resulting in the formation of deposits. 
Only some volatile metal compounds are deposited in the form of precipitates and are soluble in oil. The existence of volatile metal compounds produced during biogas combustion and emitted into the air with exhaust gases are not fully identified theoretically.

The deposits in engine powered by biogas from waste-water plant contain high concentrations of bismuth, silicon, calcium and sulphur in the head region; while in deposits on piston and in the exhaust manifold zinc concentration increases.

The deposits in the gas engines powered by landfill biogas are characterized by high contents of silicon, calcium, phosphorus, sulphur and zinc.

\section{Acknowledgements}

This research was supported by Provincial Fund for Environmental Protection and Water Management in Gdansk (project no. WFOŚ/D/748/20/2018).

\section{References}

[1] Gatidou G, Arvaniti OS, Stasinakis AS, Thomaidis NS, Andersen HR. Bioresour Technol. 2016;221:205-13. DOI: 10.1016/j.biortech.2016.09.018.

[2] Bolado-Rodríguez S, Toquero C, Martín-Juárez J, Travaini R, García-Encina PA. Bioresour Technol. 2016;201:182-90. DOI: 10.1016/j.biortech.2015.11.047.

[3] De Arespacochaga N, Valderrama C, Raich-Montiu J, Crest M, Mehta S, Cortina JL. Renew Sustain Energy Rev. 2015;52:366-81. DOI: 10.1016/j.rser.2015.07.106.

[4] Garcia M, Prats D. Int J Waste Resour. 2016;06:1-6. DOI: 10.4172/2252-5211.1000192.

[5] Soreanu G, Béland M, Falletta P, Edmonson K, Svoboda L, Al-Jamal M, et al. Can Biosyst Eng / Le Genie Des Biosyst Au Canada. 2011;53: 8.1-8.18; http://www.csbe-scgab.ca/docs/journal/53/C0815.pdf.

[6] Benato A, Macor A. Energies. 2019;12:1-31. DOI: 10.3390/en12060979.

[7] Stanuch I, Sozańska M, Biegańska J, Cebula J, Nowak J. Sci Rep. 2020;10:1-12. DOI: 10.1038/s41598-020-61212-X.

[8] Sevimoğlu O, Tansel B. Waste Manage. 2013;33:74-80. DOI: 10.1016/j.wasman.2012.08.016.

[9] Dewil R, Appels L, Baeyens J. Energy Convers Manage. 2006;47:1711-22. DOI: 10.1016/j.enconman.2005.10.016.

[10] Kaj L, Schlabach M, Andersson J, Palm Cousins A, Schmidbauer N, Brorström-Lundén E, et al. Siloxanes in the Nordic environment. Nordic Council of Ministers; 2006; DOI: 10.6027/TN2005-593. http://norden.diva-portal.org/smash/get/diva2:702777/FULLTEXT01.pdf.

[11] Dewil R, Appels L, Baeyens J, Buczynska A, Van Vaeck L. Talanta. 2007;74:14-9. DOI: 10.1016/j.talanta.2007.05.041.

[12] Monteith H, Yajima K, Andrews D, Steel P. Assessing feasibility of direct drive technology for energy recovery from digester biogas. 79th Annual Technical Conf WEFTEC, Dallas: 2006. Available from: https://d3pcsg2wjq9izr.cloudfront.net/files/5306/articles/11703/280.pdf.

[13] Brooke D, Crookes M, Gray D, Robertson S. Environmental Risk Assessment Report: Decamethylcyclopentasiloxane. Bristol: Environment Agency; 2009. Available from: https://assets.publishing.service.gov.uk/government/uploads/system/uploads/attachment_data/file/290561/sc ho0309bpqx-e-e.pdf.

[14] Brooke D, Crookes M, Gray D, Robertson S. Environmental Risk Assessment Report: Dodecamethylcyclohexasiloxane. Bristol: Environmental Agency; 2009. Available from: https://assets.publishing.service.gov.uk/government/uploads/system/uploads/attachment_data/file/290562/sc ho0309bpqy-e-e.pdf.

[15] Grümping R, Michalke K, Hirner AV, Hensel R. Appl Environ Microbiol. 1999;65:2276-8. DOI: 10.1128/AEM.65.5.2276-2278.1999.

[16] Ruiling G, Shikun C, Zifu L. Int J Agric Biol Eng. 2017;10:30-9. DOI: 10.3965/j.ijabe.20171001.3043.

[17] Wang G, Zhang Z, Hao Z. Crit Rev Environ Sci Technol. 2019;49:2257-313. DOI: 10.1080/10643389.2019.1607443.

[18] Shen M, Zhang Y, Hu D, Fan J, Zeng G. Environ Sci Pollut Res. 2018;25:30847-62. DOI: 10.1007/s11356-018-3000-4.

[19] Gaj K. Clean Technol Environ Policy. 2017;19:2181-9. DOI: 10.1007/s10098-017-1422-1. 
[20] Sadenova MA, Abdulina SA, Tungatarova SA. Clean Technol Environ Policy. 2016;18:449-59. DOI: 10.1007/s10098-015-1018-6.

[21] Oshita K, Omori K, Takaoka M, Mizuno T. Energy Convers Manage. 2014;81:290-7. DOI: 10.1016/j.enconman.2014.02.050.

[22] Kajolinna T, Aakko-Saksa P, Roine J, Kåll L. Fuel Process Technol. 2015;139:242-7. DOI: 10.1016/j.fuproc.2015.06.042.

[23] Ajhar M, Wens B, Stollenwerk KH, Spalding G, Yüce S, Melin T. Talanta. 2010;82:92-8. DOI: 10.1016/j.talanta.2010.04.001.

[24] Schweigkofler M, Niessner R. Environ Sci Technol. 1999;33:3680-5. DOI: 10.1021/es9902569.

[25] Raich-Montiu J, Ribas-Font C, de Arespacochaga N, Roig-Torres E, Broto-Puig F, Crest M, et al. Anal Chim Acta. 2014;812:83-91. DOI: 10.1016/j.aca.2013.12.027.

[26] Gersen S, Visser P, van Essen M, Brown M, Lewis A, Levinsky H. Renew Energy. 2019;132:575-86. DOI: 10.1016/j.renene.2018.07.143.

[27] Sevimoğlu O, Tansel B. J Environ Manage. 2013;128:300-5. DOI: 10.1016/j.jenvman.2013.05.029.

[28] Surita S, Tansel B. Renew Energy. 2015;80:674-81. DOI: 10.1016/j.renene.2015.02.060. 